\title{
Role of Family Communications in Adolescent Personal and Social Identity
}

\author{
Maulana Rezi Ramadhana ${ }^{\left.1,2^{*}\right)}$, Ravik Karsidi ${ }^{3}$, Prahastiwi Utari ${ }^{2}$, Drajat Tri Kartono ${ }^{4}$ \\ ${ }^{1}$ Communication Science, School of Communication and Business \\ Telkom University, Bandung, 40257, Indonesia \\ ${ }^{2}$ Communication Science, Faculty of Social and Political Science \\ Sebelas Maret University, Surakarta, 57126, Indonesia \\ ${ }^{3}$ Education Science, Faculty of Teacher Training and Education Science \\ Sebelas Maret University, Surakarta, 57126, Indonesia \\ ${ }^{4}$ Sociology Science, Faculty of Social and Political Science \\ Sebelas Maret University, Surakarta, 57126, Indonesia \\ *) Corresponding author: maulanarezi@ gmail.com
}

\begin{abstract}
This study examines the relationship between family communication patterns (involving two dimensions of conversation and conformity) and the personal-social identity of adolescents. This study uses a survey technique involving 214 adolescents from intact families and singleparent families in one school in Bandung, by providing two scales of the Family Communication Pattern Revised (FCPR) from Ritchie and the scale of Social IdentityPersonal Identity (SIPI) from Nario-Redmond. Data analysis to test three hypotheses in this study using Pearson product-moment correlation and regression analysis to find moderation of the measured variables. The findings indicate that the dimensions of the conversation are significantly positively related to social identity and personal identity. While the dimensions of conformity are negatively associated with social identity and positively associated with personal identity. After controlling for family status and sibling position in the family, the dimensions of conformity moderate significantly positive relationships between dimensions of conversation and social identity.
\end{abstract}

Keywords: Family Communication Pattern, Conversation, Conformity, Social Identity, Personal Identity

\begin{abstract}
Abstrak
Studi ini menguji hubungan antara pola komunikasi keluarga (melibatkan dua dimensi percakapan dan konformitas) dan identitas pribadi-sosial remaja. Studi ini menggunakan teknik survei yang melibatkan 214 remaja dari keluarga utuh dan keluarga single-parent di satu sekolah di Bandung, dengan memberikan dua skala instrumen Pola Komunikasi Keluarga Revised (FCPR) dari Ritchie dan skala Social Identity-Personal Identity (SIPI) dari Nario-Redmond. Analisis data untuk menguji tiga hipotesis dalam penelitian ini menggunakan korelasi product-moment Pearson dan analisis regresi untuk menemukan

moderasi dari variabel yang diukur. Hasil temuan menunjukkan bahwa dimensi percakapan secara siginifikan berhubungan positif dengan identitas sosial dan juga identitas
\end{abstract}


pribadi. Sementara dimensi konformitas berhubungan negatif dengan identitas sosial dan secara positif terkait dengan identitas pribadi. Setelah mengendalikan status keluarga dan urutan posisi anak di keluarga, dimensi konformitas memoderasi hubungan positif secara signifikan antara dimensi percakapan dan identitas sosial.

Kata kunci: Pola Komunikasi Keluarga, Percakapan, Konformitas, Identitas Sosial, Identitas Pribadi

\section{Introduction}

Adolescence is a period of transition to adulthood, a period of self-exploration through interaction with family, and developing perceptions about himself (McDonald \& Kim, 2001). Adolescents gain knowledge about themselves as group members through experiences of living together with other people in the process of finding their identity. Adolescence is also seen as a chronological period between puberty and early adulthood and as a life cycle when it explores relevant life alternatives to make commitments (Marcia, 2002). Consider Erikson's (1980) thinking that there are eight main stages of ego growth, which then experience an increase of up to 64 possible psychosocial conditions (Marcia, 1998) and each stage of the problem experiences identity. Adolescents who are resolving an identity crisis are those who not only experience problems related to trust, autonomy, initiative, and industry, but also about responsibility for the challenge of developing each of the previous stages.

Although in some literature it shows that adolescence is seen as a period of individualization, but based on the latest research ideas, the concept of adolescents is placed in a greater emphasis on socialization, so it is essential for them in the process of forming identity (Newman \& Newman, 2001). The concept of the teen identity crisis described by Newman \& Newman and based on Erikson's identity thinking, the teenage period was referred to as 'Identity versus Identity Confusion,' emphasizing the search for individual identity. The development of the theory that contributes to the adolescent crisis in Sepetri explained by Marcia (1966) about the identity development model that identifies the stages that a teenager goes through in exploring their identity through social interaction, in the end, is also related to commitment to that identity.

Newman and Newman (2001) provide a greater focus of adolescent attention to social identity in developing self-identity. This focus directs the development of teenage identities that are in line with their lifestyles and also found that many teenagers will experience conflicts between their social identities and their feelings, that their individuality makes them alienated from their social groups. This shows that social identity and more are a necessary component in the formation of adolescent self-identity, however, there are many differences concerning the importance of personal and social identity. Josselson (1994) argues that adolescents need close relationships to develop rather than psychological distance. Strong relationships with family and friends in the social environment are seen as essential and useful for integrated self-identity (Stringer, 1997; Chickering \& Reisser, 1993).

The essence of the relationship with the family is the ability of children and parents to interact to coordinate the activities and responsibilities of care and to support one another in 
raising children (Feinberg et al., 2007). Thus, communication within the family can function as a link to the process of a teenager's identity. This considers the idea of previous research that has shown that family communication patterns are central to family functions (Schrodt, 2005) and as predictors of psychosocial processes, behaviors, and results in their children. (Schrodt, Witt, \& Messersmith, 2008). Koerner and Fitzpatrick (2002a) assert that communication behavior in families is generally a result of cognitive processes that are based on a family relationship scheme.

Through the scheme, we will discuss how parents communicate with each other and with their children and relate to communicative behavior that is done in the family when family members are involved in each other's family (Koerner \& Fitzpatrick, 2002b). It is the reason why this paper was made that the process of adolescents' self and social identity in this era of technological change may still be relevant about their family's communication patterns. To test this thinking, researchers examine the extent to which the role of family communication is related to the personal and social identity of adolescents, which is vital in the era of current technological change.

\section{Theoretical Review}

In the theory of family communication patterns, the family system functions as the primary socialization agent for children and influences the behavior of children when they leave home (Koerner \& Schrodt, 2014). On the other hand, cognitive orientation appears as a function of parent-child interaction and the drive to achieve shared social reality. This orientation will shape how one views their social environment and communicates inside and outside the family. That is, family members will make their social reality through their interactions with each other and develop an understanding scheme used by family members to produce and interpret messages (Koerner \& Fitzpatrick, 2002a). The theory of family communication patterns arises from the process of co-orientation, namely when two or more individuals focus their cognitive attention on the same object in their social environment, things will shape beliefs and attitudes about objects (Newcomb, 1953). In the family communication pattern theory also explained that family members would coordinate perspectives among family members and try to reach an agreement through two different processes, which create two dimensions (in some literature called climate) in family communication.

First, the dimension of conversation. This dimension refers to the extent to which families create a communication environment where all family members are encouraged to participate in uncontrolled interactions on various topics (Koerner \& Schrodt, 2014). Families that are oriented towards a strong dimension of conversation will emphasize the importance of open communication in providing education and socializing their children, they will actively interact with each other to share ideas on various topics, express feelings and be involved together in decision making. While families with weak conversations can be seen in families with rare interactions, there are no transaction messages, thoughts, feelings, and activities together. Second, the dimensions of conformity. This dimension emphasizes the extent to which family communication creates a climate of homogeneity in attitudes, values, and beliefs (Koerner \& Fitzpatrick, 2002a). Families that are oriented to the dimensions of conformity who strongly believe in the importance of uniformity and compliance with 
parental authority, they often make decisions for the whole family without consulting their children, especially in the decision-making process. This conformity-oriented family has a uniform belief and value system among family members, has a hierarchical family structure, and they place family interests above individual interests. While families with low confessions emphasize individual beliefs, there is equality and individual growth of each family member (Koerner \& Fitzpatrick, 2002b). These two family communication orientations often interact to create four types of family, protective (characterized by strong conformity but weak conversation), pluralistic (characterized by weak conformity but strong conversation), consensual (characterized by strong conformity and conversation) and laissezfaire (characterized by conformity and weak conversation).

In a meta-analytical review of the literature on family communication patterns, Schrodt et al. (2008) concluded that children from families who have high conversational dimensions are more competent and flexible communicators in various contexts. Schrodt et al. (2009) also showed that children from conversation-oriented families viewed their parents as more relevant in communicating. Given that a high dimension of conversation reflects openness that encourages dialogue and social interaction that supports various topics, it must be linked to the acquisition of social and personal identity, as stated in hypothesis $1(\mathrm{H} 1)$ :

H1: a) The dimensions of conversation in the family are positively related to social identity, and $b$ ) negatively related to personal identity

Based on the study, there is a lot of empirical evidence about the dimensions of conformity which states that there is an adverse effect on the existence of these dimensions on the results of behavior in an interaction relationship. For example, research conducted by Koerner and Cvancara (2002) found that family members oriented to conformity were more dominant in having a self-orientation rather than interpersonal interaction and conversation in the social environment. The researchers also found that the dimensions of conformity tended to inhibit, rather than increase (Koerner \& Fitzpatrick, 2002c) and occur within the family (Schrodt \& Ledbetter, 2007). Harmon and Schrodt (2012) suggested that the dimensions of high conformity instilled conversation in the family and very closely with authoritarian parenting styles (characterized by high control and low warmth). Thus, it must also be associated with social identity and, as stated in hypothesis 2 (H2):

H2: a) The dimensions of conformity in the family are negatively related to social identity, and b) positively related to personal identity.

For the latest consideration from Koerner \& Schrodt (2014) and supported by empirical evidence from Ledbetter \& Schrodt (2008) which suggests that the dimensions of conformity can moderate the relationship between conversation and social-personal identity. In this study, for example, adolescents from pluralistic families might feel that their parents are more mutually supportive to foster personal and social identity than adolescents with protective family styles, because of the high dimension of conversation in the family. Or maybe teens from consensual families can strengthen personal identity than people from pluralistic families because of the increased pressure felt in consensual families in reaching an agreement, despite having open conversations about various topics. Although the certainty of the impact of the interaction is unknown, logically, the dimensions of conformity tend to 
change the relationship between the dimensions of conversation and personal-social identity. Thus, researchers submit the final hypothesis (H3) :

H3: The dimensions of family conformity will moderate the relationship between dimensions of family conversation and social identity.

\section{Participants}

\section{Methods}

Respondents in the study involved 214 high school adolescents from intact families $(n=$ $144)$ and single parent families $(\mathrm{n}=70)$ in one Bandung high school. The sample was 78 boys and 135 teenage girls ranging in age from 16-18 with an average age of 17.2 years (SD $=0.53)$. Most of the respondents were Sundanese $(67.2 \%, n=145)$ and the rest were Javanese $(32.7 \%, n=69)$. Respondents were single children $(6.5 \%, n=14)$, eldest with one younger sibling $(20.6 \%, n=44)$, eldest with two younger siblings $(11.2 \%, n=24)$, eldest with three younger siblings $(4.2 \%, n=9)$, the eldest with four younger siblings $(0.9 \%, n=2)$, second child one sister brother $(34.1 \%, n=73)$, second with one brother and sister $(3.3 \%, n=7)$, youngest one brother $(9.3 \%, n=20)$ youngest two sisters $(3.7 \%, n=8)$ youngest three sisters $(3.7 \%, n=8)$ and youngest four siblings $(2.3 \%, n=5)$. Adolescents from intact families reported that their parents were married with an average age of marriage of 26.9 years $(S D=$ $3.55 ; n=144$, range $=17-41$ years), while those from single-parent families reported average one of the parents has left an average of 5.1 years $(S D=2.04 ; n=70$, range $=2-10$ years left $)$ with the cause of divorce $(34.3 \%, n=24)$, father died $(28.6 \%, \mathrm{n}=20)$, mothers died $(18.6 \%$, $\mathrm{n}=13)$ and father-mothers died $(18.6 \%, n=13)$.

\section{Procedure}

After determining the variation of the respondent and getting approval from the school, the researcher entered the special classroom and asked the respondents to fill out the questionnaire voluntarily. The implementation of the research has been permitted by the Principal, and the counter-supervising teacher gets additional assignment scores on one particular subject. The implementation was carried out in the morning, filling out the questionnaire was completed in the range of 42 minutes.

\section{Measurement}

\section{Family Communication Pattern}

The pattern of family communication is measured using the Family Communication Pattern Revised (RFCP) scale (Ritchie, 1991). The instrument consisted of 26 items that asked respondents to evaluate the extent to which their family communication patterns reflected the conversation dimension (as many as 15 items, such as the example item, "My parents encouraged me to issue ideas," I really enjoyed talking to my parents ") and the dimensions of conformity (as many as 11 items, such as an example item, "My parents often say things like "You have to follow the rules and don't make people angry") Response using a 5-point Likert scale ( $1=$ very inappropriate, up to $5=$ very appropriate. The validity and reliability of the family communication pattern instrument are quite good (Schrodt et al., 
2008), and in this study, conversation and conformity resulted in an alpha coefficient of 0.885 for the conversation dimension and 0.726 for dimensions of conformity.

\section{Personal and Social identity}

Personal and social identity is measured using the scale of Social Identity and Personal Identity (SIPI) (Nario-Redmond, Biernat, Eidelman \& Palenske, 2004). Participants completed 16 items (8 items for social identity with sample items, "I have membership in various groups" and eight items to measure SIPI's identity with sample items, "my creativity," "my freedom from others"). The response to SIPI ranges from 1 (not at all important to me) to 9 (very important for me). In this study, the scale produces very good internal reliability with an alpha coefficient of 0.913 for social identity and 0.903 personal identities.

\section{Data analysis}

The first two hypotheses were tested using the Pearson product-moment correlation, while to test Hypothesis 3, two separate hierarchical regression analyses were conducted to measure social identity and personal identity. For both models, theoretically relevant control variables (family status and sibling position) are included in the first step, followed by the conversation dimension and the dimensions of conformity in the second step, and the interaction terms of both dimensions (conversation and conformity) in the third step. Researchers follow the advice of Little, Card, Bovaird, Preacher, and Crandall (2007), the term dimensional interaction is made by concentrating the first part predictor and orthogonalization by regressing it to the first part predictor and storing non-standardized residues.

\section{Findings \& Discussion}

\section{Preliminary Analysis}

Descriptive statistics, averages, standard deviations, and Pearson product-moment correlations are presented in Table 1 . The initial analysis was conducted to determine whether age, gender (code $0=$ teenage boys, $1=$ teenage girls), sibling position, the age of marriage of parents, single-parent status (code $0=$ whole family, $1=$ single-parent family), associated with social and personal identity. The results show that the age of parental marriage is not significantly related to social and personal identity $(r=-.11, p=0.10)$. Age is not related to social and personal identity $(r=-.04, p=0.52)$. Likewise, there is no gender difference with social identity and personal identity $(r=-.08, p=0.65)$.

Two-one way ANOVA revealed that adolescents from intact families supported social identity more $(M=5.07, S D=1.73)$ than respondents from single-parent families $(M=4.71$, $S D=1.34), F(1,212)=2,308, p=.130, \eta 2=.11$, and personal identity $(\mathrm{M}=4.87, \mathrm{SD}=$ 1.65) compared to single-parent families $(M=4.78, S D=1.46), F(1,212)=0.137, p=7.12$, $\eta 2=.01$. Likewise the order of family children has a small relationship, although not significant with social identity $(r=.011, p=.186)$ and ignores the relationship with personal identity $(r=-.017, p=.978)$. As a result, we include the status of the family condition (intactsingle-parent and sibling position as control variables in our regression model).

Table 1 Descriptive Statistics and Pearson Product-Moment Correlation (All variables) 


\begin{tabular}{llllllll}
\hline Variables & $\mathbf{M}$ & SD & $\mathbf{1}$ & $\mathbf{2}$ & $\mathbf{3}$ & $\mathbf{4}$ & $\mathbf{5}$ \\
\hline 1. Sibling position & 1.83 & 0.95 & - & & & & \\
2. Conversation & 3.61 & 0.64 & .015 & - & & & \\
3. Conformity & 2.82 & 1.19 & .031 & .110 & - & & \\
4. Social Identity & 4.95 & 1.62 & .017 & $.220^{* *}$ & -.023 & - & \\
5. Personal Identity & 4.84 & 1.59 & -.084 & .088 & .023 & $.664^{* *}$ & - \\
\hline **. Correlation is significant at the 0.01 level (1-tailed).
\end{tabular}

H1a and b partially support, although the conversation dimension is significantly positively related to social identity $(r=.22, p<.001)$ as well as personal identity $(r=.088$, $p>.001)$, although not significant. While $\mathrm{H} 2 \mathrm{a}$ and $\mathrm{b}$ fully support, that dimension of conformity is negatively related to social identity $(r=-.026, p>.001)$, and positively related to personal identity $(r=.023, p>.001)$.

$\mathrm{H} 3$ predicts that the orientation of family conformity will moderate the relationship between family conversation orientation and social and personal identity. The first regression model uses social identity as a criteria variable that produces multiple correlation coefficients, $R=.24, F(4,203)=3.204, p<.05$. In the first step, family status (intact and single-parent $)(\beta=.73, \mathrm{t}=2,009, p<.05)$ and the order of children in the family $(\beta=-.251$, $t=-2.13, p<.05)$ is a significant predictor in the model. In the second step, the conversation dimension $(\beta=.42, t=2.27, p<.05)$ emerged as the only significant predictor in the model. In the third step, the term interaction is not statistically significant.

The second regression model uses personal identity as a criterion variable. This model also produces a significant multiple correlation coefficient, $R=1.34, F(4,203)=2,413, p<$ .05. In the first step, family status (intact and single-parent) $(\beta=.55, t=1.51, p<.05)$ is the only significant predictor in the model. In step two, the conversation dimension $(\beta=.26, t=$ $1.41, p<.05)$ and the dimensions of conformity $(\beta=.40, t=1.38, p<.05)$ emerged as significant predictors in the model. In the third step, the interaction of the conversation dimension with the dimensions of conformity has a positive relationship even though it is not statistically significant $(\beta=.12, t=1.60, p=.11)$. This interaction effect is decomposed using the procedure described by Aiken and West (1991). The dimensions of conformity moderated the positive positive relationship between the dimensions of conversation and social identity $(b=.19, z=2.68, p<.05)$. The hypothesis 3 is supported by data.

\section{Conclusion}

\section{Conclusion and Recommendation}

Most support the theoretical reasoning put forward in this paper. Consistent with Stringer's idea (1997) that a strong relationship with the family in the social environment is useful for integrated teen identity. Although the dimensions of the conversation are significantly positively related to social identity but also positively related to personal identity. While the dimensions of conformity are negatively related to social identity and positively related to personal identity. And the dimensions of conformity significantly predict the dimensions of the conversation but do not directly moderate social and personal identities. 
As a result, this broadens the idea of family communication patterns and models of social and personal identity by providing these three findings.

The results underscore the importance of the dimensions of conversation within the family with the social identity and personal identity of the teenager. That is, parents in the family believe in the value of open and uncontrolled interactions on various topics may be more inclined to provide support in shaping their real understanding of social adolescents, as well as their understanding. It can be said that interpersonal communication skills in conversation function as family resources that can help develop teen identity. In line with the findings of Schrodt et al. (2009), through the results of his research showing that parents who create high conversations in the family are considered more likely to cooperate. Likewise, we judge that the social identity of adolescents is important and related to his identity. The relationship between social identity and personal identity during adolescence can be complementary (Nario-Redmond et al., 2004), when adolescents seek supportive relationships from a group environment, they find ways in which the community works and their place in it.

The results show a more nuanced picture of how the dimensions of conformity in the family are positively related to personal identity and negatively related to their social identity. Although the orientation of conformity is negatively related to communication of social identity, it may be less important to occupy a personal identity if parents have established strong conversations in the family. Conversely, when parents emphasize that all family members adopt the same attitudes, beliefs, and rules by mobilizing their authority in the family, the accompanying pressure may damage their exploration in their social identity, the limitations that accompany adolescents to understand the position himself in the social environment, we judge the existence of a conflict. Back in the condition of the development of teen identity, which is in line with the development of his lifestyle. This is in line with the idea that high conformity orientations tend to inhibit families from resolving conflicts and modeling healthy conflict resolution skills for their children (Koerner \& Fitzpatrick, 1997, 2002c), perhaps conformity orientation encourages avoidance of conflict in care, but in reality conformity strong encourages parents to act independently and raises a push back in personal identity.

The results of this study extend the notion of family communication pattern theory by explaining the moderating role of conformity dimensions in explaining the relationship between the dimensions of conversation and social identity. It can be said that the role of conformity in the family will influence and moderate their conversation patterns in the social identity of adolescents. The presence of this dimension of conformity is a determining factor on how conversation becomes a process. This supports previous studies by Koerner and Cvancara (2002), which predicted that conformity would manifest itself at the micro level in family conversations. Their research shows that high conformity orientation can be associated with verbal communication that leads to the process of social and personal identity.

The main purpose of this study is to examine the extent to which Family Communication Patterns are associated with adolescent social and personal identities, through three proposed hypotheses it can be concluded that the dimensions of conversation are positively related to social identity and personal identity. And the dimensions of conformity are negatively related to social identity and positively related to the personal identity of adolescents, this dimension 
also significantly predicts the dimensions of conversation, and does not directly moderate social and personal identity.

\section{Recommendation}

The results of this study must be interpreted with caution, given the limitations inherent in research design. The use of data (cross-section) is a buffer between causality in the data. Perhaps the development of adolescents in developing a social or personal identity during the transition period develops and changes. Several factors, such as the quality and duration of the conversation, are the focus that can be studied more deeply in connecting with the dimensions of conformity. This is also limited to demographic data that are expected to be more varied.

The researchers can find patterns of relationships that differ between family communication and social-personal identity according to the age of adolescence and family type based on economic, cultural, etc. For future researchers, it may also be necessary to expand this research study by positioning social-personal identity as a mechanism for a more in-depth explanation of how conversations and conformity carry out family functions in achieving family resilience. By continuing to investigate the relationship of adolescent social-personal identity, researchers can continue practical handling in parenting efforts for intact families and single-parent.

\section{Acknowledgment}

On behalf of this research, the authors express their gratitude to the Principal of the High School in the City of Bandung, who has given students access to data collection.

Orchid author ID: http://orcid.org/0000-0002-7683-7777

\section{References}

Aiken, L. S., \& West, S. G. (1991). Multiple regression: Testing and interpreting interactions. Newbury Park, CA: Sage

Chickering, A. W. \& Reisser, L. (1993). Education and identity. 2nd ed. San Francisco: Jossey Bass.

Erikson, E. H. (1980). Identity and the life cycle: A reissue. New York: Norton

Feinberg, M. E., Kan, M. L., \& Hetherington, E. M. (2007). The longitudinal influence of co-parenting conflict on parental negativity and adolescent maladjustment. Journal of Marriage and Family, 69, 687-702

Josselson, R.L. (1994). Identity and relatedness in the life cycle. In H.A. Bosma, D.J.de Levita, T.L.J. Grastina\& H.D. Grotevant eds. Identity and Development: An Interdisciplinary Approach. Thousand Oaks, CA: Sage, pp.81-102

Koerner, A. F., \& Cvancara, K. E. (2002). The influence of conformity orientation on communication patterns in family conversations. The Journal of Family Communication, 2, 133-152. doi:10.1207/S15327698JFC0203_2

Koerner, A. F., \& Fitzpatrick, M. A. (2002a). Toward a theory of family communication. Communication Theory, 12, 70-91. doi:10.1111/j.1468-2885.2002.tb00260.x 
Koerner, A. F., \& Fitzpatrick, M. A. (2002b). Understanding family communication patterns and family functioning: The roles of conversation orientation and conformity orientation. Communication Yearbook, 26, 36-68. doi:10.1207/s15567419cy2601_2

Koerner, A. F., \& Fitzpatrick, M. A. (2002c). You never leave your family in a fight: The impact of family of origin on conflict-behavior in romantic relationships. Communication Studies, 53, 234-251. doi:10.1080/10510970209388588

Koerner, A. F., \& Schrodt, P. (2014). An introduction to the special issue on family communication patterns theory. Journal of Family Communication, 14, 1-15. doi:10.1080/ 15267431.2013.857328

Little, T. D., Card, N. A., Bovaird, J. A., Preacher, K., \& Crandall, C. S. (2007). Structural equation modeling of mediation and moderation with contextual factors. In T. D. Little, J. A. Bovaird, \& N. A. Card (Eds.), Modeling contextual effects in longitudinal studies (pp. 207-230). Mahwah, NJ: Erlbaum

Marcia, J. E. (1998). Optimal development from an Eriksonian perspective. In Encyclopedia of Mental Health Vol. 3 (pp. 29-39). San Diego, CA: Academic.

Marcia, J. E., 1966. Development and validation of ego identity statuses. Journal of personality and social psychology. 3(5), pp. 551-558

Marcia, J.E (2002) Adolescence, Identity, and the Bernardone Family, Identity: An International Journal of Theory and Research, 2:3,199-209

McDonald D.G \& Kim H . (2001). When I Die, I Feel Small: Electronic Game Characters and the Social Self. Journal of Broadcasting \& Electronic Media, 45(2), pp. 241-258.

Nario-Redmond, MR, Biernat.M, Eidelman.S, \& Palenske, D. (2004). The Social and Personal Identities Scale: A Measure of the Differential Importance Ascribed to Social and Personal Self-Categorizations. Self and Identity. 3. pp 143-175

Newcomb, T. M. (1953). An approach to the study of communicative acts. Psychological Review, 60, 393-404. doi:10.1037/h0063098

Newman, B. M., P. R. Newman, 2001. Group Identity and Alienation: Giving the We Its Due. Journal of Youth and Adolescence. 30 (5), pp. 515.

Ritchie, L. D. (1991). Family communication patterns: An epistemic analysis and conceptual reinterpretation. Communication Research, 18, 548-565. doi:10.1177/009365091018004005

Schrodt, P. (2005). Family communication schemata and the circumplex model of family functioning. Western Journal of Communication, 69, 359-376. doi:10.1080/10570310500305539

Schrodt, P., Ledbetter, A. M., Jernberg, K. A., Larson, L., Brown, N., \& Glonek, K. (2009). Family communication patterns as mediators of communication competence in the parent-child relationship. Journal of Social and Personal Relationships, 26, 853-874. doi:10.1177/ 0265407509345649

Schrodt, P., Witt, P. L., \& Messersmith, A. S. (2008). A meta-analytical review of family communication patterns and their associations with information processing, behavioral, and psychosocial outcomes. Communication Monographs, 75, 248-269. doi: $10.1080 / 03637750802256318$

Schrodt, P., \& Shimkowski, J. R. (2015). Family Communication Patterns and Perceptions of Coparental Communication. Communication Reports, 30(1), 39-50. doi:10.1080/08934215.2015.1111400 
Ramadhana, et al. / Journal of Family Sciences, 2019, Vol. 04, No. 01

Stringer, S. A. (1997). Conflict and Connection: The Psychology of Young Adult Literature. Portsmouth, Boynton: Cook Publishers, Inc 